\title{
PENGARUH LATIHAN FISIK TERHADAP KEMAMPUAN KOGNITIF LANSIA DI DESA NGESREP KECAMATAN NGEMPLAK KABUPATEN BOYOLALI
}

\author{
Andreany Kusumowardani, Endang Sri Wahyuni \\ Kementerian Kesehatan Politeknik Kesehatan Surakarta Jurusan Okupasi Terapi
}

\begin{abstract}
Exercise, Older People, Cognitive Performance, MMSE. Cognitive performance in older people declines gradually due to aging process. It raises problems in functional daily activities, risks of injury, and dependency. Literatures have been revealed the benefits of exercise for health, not only physically, but also mentally. The purpose of this study was to determine the effect of exercise on the cognitive performance of older people in Ngesrep Village, Boyolali District. This study was a quasi experimental one group pre test-post test with control group. A constitutive sampling method was applied to get subjects, and found 20 people for each experiment and control group. The instrument used was Mini Mental State Examination (MMSE). Based on paired t-test analysis in the experiment group, it was found a significant difference on the cognitive performance pre and post exercise intervention ( $\alpha=0.05, t$ $=2.492, p=0.022, r=0.657)$. In the control group, there was no diferrence in pre and post test $(p=0.053)$. Based on independent $t$-test analysis between experiment and control group, it was found a significant difference before the intervention $(p=0.031)$, but after the intervention, there was no difference between the two groups. It was due to the increasing MMSE's score on the experiment group, whereas the score of control group was relatively the same. Physical exercise had a significant influence on the cognitive performance of older people in this study, so it should be held in Ngesrep Village's Posyandu routinely.
\end{abstract}

Keywords : Exercise, Older People, Cognitive Performance, MMSE

Abstrak : Latihan Fisik (Exercise), Lansia, Kemampuan Kognitif, MMSE. Kemampuan fungsi kognitif pada lansia umumnya mengalami penurunan sejalan dengan pertambahan usia. Akibat adanya penurunan fungsi kognitif, kemampuan lansia dalam melaksanakan aktivitas fungsional juga mengalami gangguan, resiko terjadinya kecelakaan meningkat, dan akan meningkatkan ketergantungan pada orang lain. Berbagai literatur telah mengungkapkan manfaat latihan fisik (physical exercise) bagi kesehatan, termasuk dalam kesehatan mental dan kognitif. Penelitian ini bertujuan untuk menguji pengaruh latihan fisik terhadap kemampuan kognitif lansia di Desa Ngesrep, Kecamatan Ngemplak, Kabupaten Boyolali. Penelitian ini merupakan penelitian eksperimental semu menggunakan desain one group pre test post test dengan kelompok kontrol. Sampel adalah lansia di Desa Ngesrep sebanyak 20 orang kelompok perlakuan dan 20 orang kelompok kontrol dengan metode constitutive sampling. Instrumen yang digunakan untuk mengukur kemampuan kognitif adalah Mini Mental State Examination (MMSE). Analisis data yang digunakan adalah Paired t-test pada masing-masing kelompok dan Independent t-test untuk antar kelompok. Berdasarkan analisis Paired $t$ - 
test kelompok perlakuan diperoleh hasil bahwa terdapat perbedaan yang bermakna pada kemampuan kognitif lansia antara sebelum dan setelah pemberian latihan fisik, di mana latihan fisik memberikan pengaruh yang kuat dan positif pada kemampuan kognitif lansia $(\alpha=0.05, \mathrm{t}=2.492, \mathrm{p}=0.022, \mathrm{r}=0.657)$. Pada kelompok kontrol tidak ditemukan perbedaan kemampuan kognitif pada pre dan post test $(\mathrm{p}=0.053)$. Berdasarkan analisis Independent t-test antara kelompok perlakuan dan kontrol, diperoleh nilai $\mathrm{p}=0.031$ sebelum perlakuan, yang berarti terdapat perbedaan yang bermakna pada kemampuan kognitif kelompok kontrol dan kelompok perlakuan, di mana kelompok kontrol memiliki kemampuan kognitif yang lebih tinggi dibandingkan kelompok perlakuan. Setelah intervensi latihan fisik diperoleh $p=0.198$, yang berarti tidak terdapat perbedaan yang bermakna pada kemampuan kognitif kelompok perlakuan dan kontrol karena terdapat peningkatan nilai kognitif pada kelompok perlakuan sedangkan pada kelompok kontrol relatif tidak banyak perubahan. Latihan fisik memberikan pengaruh positif terhadap kemampuan kognitif lansia sehingga perlu dilakukan secara rutin dan diagendakan dalam kegiatan Posyandu Lansia di Desa Ngesrep, Kec. Ngemplak, Kab. Boyolali.

Kata Kunci : Latihan Fisik (Exercise), Lansia, Kemampuan Kognitif, MMSE

\section{PENDAHULUAN}

Kelompok lanjut usia (lansia) di Indonesia menunjukkan kecenderungan peningkatan dalam jumlah dan proporsinya seiring dengan peningkatan angka harapan hidup. Jika menggunakan model proyeksi penduduk dari PBB, jumlah lansia di Indonesia pada tahun 2050 diprediksikan meningkat lebih dari empat kali lipat dibandingkan tahun 2010 yaitu menjadi 120 juta jiwa lebih (BAPPENAS, 2007). Adanya peningkatan jumlah lansia yang cukup besar ini dapat menimbulkan permasalahan baru. Proses degeneratif yang terjadi seiring dengan menuanya seseorang, akan menyebabkan berbagai masalah fisik, kognitif, psikologis, dan sosial (Dewi et al., 2007).

Penurunan fungsi kognitif umumnya dialami lansia sebagai akibat dari proses penuaan. Penurunan kognitif ini semakin nyata jika terdapat penyakit yang menyertai, misalnya Alzheimer. Dampak dari penurunan fungsi kognitif ini akan menyebabkan keterbatasan dalam melaksanakan aktivitas fungsional. Kecelakaan-kecelakaan kecil dapat terjadi akibat penurunan kewaspadaan, dan rasa cemas serta ketakutan dapat meningkat akibat gangguan orientasi. Kemampuan berpikir, daya ingat, dan pemecahan masalah yang berkurang menyebabkan lansia kesulitan dalam melaksanakan aktivitas sehari-hari, bahkan dalam aktivitas rutin yang sebelumnya dapat dilakukan dengan mudah. Jika masalah kognitif ini tidak diatasi dengan baik, akan meningkatkan ketergantungan lansia pada orang lain.

Banyak literatur telah mengungkapkan bahwa latihan fisik memberikan manfaat besar bagi kesehatan. Aktivitas ini tidak hanya mencegah dan mengurangi resiko berbagai penyakit, tetapi secara klinis juga berperan dalam penyembuhan dan pemulihan dari penyakit (Powers \& Howley, 2001). Hal ini dimungkinkan karena latihan fisik menyebabkan berbagai perubahan fisiologis yang 
memberikan dampak positif bagi tubuh, seperti memperbaiki kerja jantung, memperlancar aliran darah, mengontrol kadar gula darah, serta meningkatkan kekuatan otot dan daya tahan tubuh (Wilmore, Castill, \& Kenney, 2008).

Selain memberikan manfaat jasmani, latihan fisik juga berperan dalam kesehatan mental dan kognitif. Latihan fisik dapat menurunkan ketegangan dan kelelahan pikiran, meningkatkan motivasi, memberikan perasaan keberhasilan ( $a$ sense of achievement), meningkatkan kegembiraan, dan kehidupan sosial yang lebih baik (Mental Health Foundation, 2012).

Desa Ngesrep Kecamatan Ngemplak Boyolali merupakan salah satu desa binaan Politeknik Kesehatan Surakarta. Posyandu lansia yang ada di sana sudah berjalan dengan baik, tetapi tidak banyak lansia yang berpartisipasi di dalamnya. Demikian juga kegiatan senam lansia sudah dijalankan, tetapi tidak dilaksanakan secara rutin. Penelitian ini dilakukan untuk mengetahui pengaruh latihan fisik (senam) terhadap kemampuan kognitif lansia di Desa Ngesrep sehingga diharapkan akan memotivasi lansia untuk terus aktif dan meningkatkan partisipasi lansia dalam kegiatan Posyandu.

\section{METODE PENELITIAN}

Penelitian ini merupakan penelitian kuantitatif dengan bentuk eksperimen semu menggunakan desain one group pre test post test dengan kelompok kontrol. Populasi penelitian adalah semua lansia di desa Ngesrep Kecamatan Ngemplak Boyolali. Teknik pengambilan sampel menggunakan teknik constitutive sampling. Jumlah sampel sebanyak 40 orang, meliputi 20 orang sebagai kelompok perlakuan dan 20 orang lainnya sebagai kelompok kontrol. Kelompok kontrol ini diperlukan sebagai pembanding karena berdasarkan teori, proses penuaan akan berdampak pada penurunan kemampuan kognitif. Melalui penelitia ini akan dapat diketahui apakah perlakuan yang diberikan berpengaruh pada proses penurunan kemampuan kognitif ini. Kriteria inklusi sampel: lansia berusia 50 tahun atau lebih dan tingkat kesadaran terhadap waktu, tempat, dan orang cukup baik. Kriteria eksklusi: lansia dengan gangguan gerak dan mobilitas, serta penyakit kronis yang akan meningkat gejalanya dengan latihan fisik.

Latihan fisik yang dilakukan meliputi latihan aerobik (aerobic exercise), latihan kekuatan dengan tahanan (strength/resistance exercise), dan latihan kelenturan (flexibility exercise). Latihan aerobik yang dilakukan meliputi senam irama. Latihan kekuatan dengan pemberian tahanan (resistance exercise) meliputi chair raise (duduk-berdiri dari kursi tanpa berpegangan), standing pushup, calf-raise (jinjit), shoulder press, lateral arm raise, biceps curl. Latihan kelenturan (flexibility exercise) meliputi penguluran. Latihan fisik ini dilakukan 2 kali perminggu, dengan durasi 30-45 menit, selama 6 minggu.

Kemampuan kognitif yang diukur meliputi kemampuan orientasi, atensi, memori, bahasa, konstruksi, kalkulasi, dan penalaran yang diukur dengan menggunakan instrument Mini Mental State Examination (MMSE). MMSE merupakan suatu skala terstruktur yang terdiri dari 30 poin yang dikelompokkan menjadi 7 kategori. Skor MMSE diberikan berdasarkan jumlah item yang benar sempurna; skor yang makin rendah mengindikasikan performance yang buruk dan gangguan kognitif yang makin parah. 
Skor total berkisar antara 0-30 dengan interpretasi: (a) Skor 24-30 diinterpretasikan sebagai fungsi kognitif normal, (b) Skor 18-23 berarti probable gangguan kognitif atau gangguan kognitif ringan, (c) Skor 0-17 berarti definite gangguan kognitif atau gangguan kognitif berat.

Data diolah menggunakan bantuan software SPSS 17.00 for windows. Pengujian hipotesis dalam kelompok (perlakuan dan kontrol) menggunakan dependent t-test sedangkan antar kelompok menggunakan independent $t$ test.

\section{HASIL PENELITIAN}

\section{Tabel 1}

Karakteristik Sampel Penelitian

\begin{tabular}{|c|c|c|}
\hline Karakteristik & $\begin{array}{c}\begin{array}{c}\text { Perlakuan } \\
(\mathrm{n}=\mathbf{2 0})\end{array} \\
\end{array}$ & $\begin{array}{c}\text { Kontrol } \\
(\mathbf{n}=\mathbf{2 0})\end{array}$ \\
\hline \multicolumn{3}{|l|}{ Usia: } \\
\hline - Minimal & 50 th & 50 th \\
\hline - Maksimal & 70 th & 73 th \\
\hline - Rerata & 60.5 th & 59.78 th \\
\hline - $\quad \mathrm{SD}$ & & \\
\hline \multicolumn{3}{|l|}{ Jenis kelamin: } \\
\hline - Perempuan & 19 & 19 \\
\hline - Laki-laki & 1 & 1 \\
\hline \multicolumn{3}{|l|}{ Skor pre test MMSE: } \\
\hline - Minimal & 12 & 13 \\
\hline - Maksimal & 30 & 29 \\
\hline - Rerata & 21.00 & 24.30 \\
\hline - $\mathrm{SD}$ & 4.995 & 4.293 \\
\hline \multicolumn{3}{|l|}{ Skor post test MMSE: } \\
\hline - Minimal & 16 & 13 \\
\hline - Maksimal & 28 & 29 \\
\hline - Rerata & 23.10 & 24.65 \\
\hline - $\mathrm{SD}$ & 3.463 & 4.004 \\
\hline
\end{tabular}

Berdasarkan tabel di atas, dapat

dilihat bahwa karakteristik sampel menurut usia dan jenis kelamin antara kelompok perlakuan dan kontrol relatif sama, di mana rerata usia kelompok perlakuan adalah 60.5 tahun, dan kelompok kontrol 59.78 tahun. Baik kelompok perlakuan maupun kontrol didominasi perempuan dengan jumlah sampel laki-laki hanya 1 orang pada masing-masing kelompok.

Skor rerata pre test MMSE pada kelompok kontrol lebih tinggi (24.30) dibandingkan kelompok perlakuan (21.00). Hal ini terjadi karena pemilihan kelompok kontrol dan perlakuan mempertimbangkan lokasi tempat tinggal subyek penelitian untuk mempermudah dalam pelaksanaan perlakuan senam. Sebagian besar subyek pada kelompok kontrol tinggal di wilayah yang dekat dengan pusat pemerintahan desa dengan akses fasilitas dan informasi yang lebih mudah dijangkau dibandingkan dengan kelompok perlakuan. Tingkat pendidikan pada kelompok kontrol pun lebih baik dibandingkan pada kelompok perlakuan. Hal ini rupanya berdampak pada nilai yang lebih baik saat pre test dengan instrumen MMSE.

Berdasarkan pemeriksaan MMSE pasca perlakuan, terdapat perubahan nilai pada kelompok perlakuan. Rata-rata nilai MMSE yang diperoleh setelah diberikan perlakuan adalah 23.10 dengan nilai terendah 16 dan nilai tertinggi adalah 28 . Dibandingkan nilai MMSE rata-rata sebelum perlakuan, terjadi peningkatan nilai sebesar 2.10 poin. Sebanyak 14 (70\%) sampel dari kelompok perlakuan mengalami peningkatan nilai MMSE, sedangkan 4 orang $(20 \%)$ nilainya tetap setelah menerima perlakuan senam dan 2 $(10 \%)$ sampel mengalami penurunan nilai MMSE setelah diberikan perlakuan.

Pada kelompok kontrol, dilakukan tes MMSE kembali setelah jeda selama 6 minggu. Tidak banyak perubahan yang terjadi pada nilai MMSE yang kedua 
dibandingkan dengan pemeriksaan pertama. Rerata nilai yang diperoleh pada pemeriksaan kedua adalah 24.65 , sedikit meningkat dibandingkan pemeriksaan pertama yang memperoleh nilai rerata 24.30. Nilai terendah dan tertinggi pada kelompok ini tidak mengalami perubahan, yaitu 13 dan 29. Sebagian besar (13 orang atau $65 \%$ ) sampel kelompok kontrol tidak mengalami perubahan pada nilai MMSE yang kedua dibandingkan nilai pada pemeriksaan pertama, 1 orang mengalami penurunan nilai, sedangkan 6 orang $(30 \%)$ mengalami peningkatan nilai.

Dengan melihat peningkatan rerata nilai MMSE yang diperoleh kelompok perlakuan, dapat disimpulkan bahwa secara umum kemampuan kognitif pada kelompok ini meningkat setelah diberikan perlakuan berupa latihan fisik. Hal ini semakin terlihat jika dibandingkan dengan kelompok kontrol, di mana kemampuan kognitifnya relatif tetap setelah dilakukan pemeriksaan dengan MMSE yang berselang 6 minggu. perlakuan dilakukan dengan menggunakan Dependent/ Paired t-test karena data yang diolah adalah data continous/interval. Selain itu, dari tes normalitas data menggunakan ShapiroWilk diperoleh nilai signifikansi 0.710 sehingga disimpulkan data terdistribusi normal. Berdasarkan analisis kelompok perlakuan, pada tingkat signifikansi $\alpha=$ 0.05 dengan $\mathrm{dk}=19$ diperoleh nilai $\mathrm{t}$ sebesar -2.492, 95\% CI (-3.864 - -0.336). Nilai t mutlak yang diperoleh lebih besar dari nilai t tabel (2.093) sedangkan nilai $\mathrm{p}$ $=0.022$, lebih kecil dari 0.05 , sehingga secara statistik dapat disimpulkan bahwa terdapat peningkatan kemampuan kognitif yang bermakna pada kelompok perlakuan setelah diberikan latihan fisik. Sedangkan kuatnya hubungan dinyatakan dalam $r$ sebesar 0.657 sehingga hubungan tersebut dikategorikan kuat dan positif.

Pada kelompok kontrol dengan tingkat signifikansi $\alpha=0.05$ diperoleh nilai $\mathrm{p}=0.053$, sedikit lebih besar dari nilai signifikansi 0.05 , sehingga disimpulkan bahwa tidak terdapat perbedaan yang bermakna pada kemampuan kognitif kelompok kontrol pada pre dan post test MMSE (Tabel 2).

\section{Tabel 2}

Analisis Perubahan Kemampuan Kognitif Pada Lansia Sebelum Dan Sesudah Diberikan Latihan Fisik Pada Kelompok Perlakuan Dan Kontrol

$\begin{array}{lllll}\text { Variabel } & n & \text { Mean } & \text { SD } & p\end{array}$

Kelompok perlakuan:

- Sebelum

- Sesudah

- Selisih

Kelompok kontrol:

- Sebelum

- Sesudah

$\begin{array}{lll}20 & 21.00 & 4.995\end{array}$

$\begin{array}{lll}20 & 23.10 & 3.463\end{array}$

$-2.10 \quad 1.532$

- Selisih

$\begin{array}{lll}20 & 24.30 & 4.293\end{array}$

$\begin{array}{lll}20 & 24.65 & 4.004\end{array}$

$\begin{array}{ll}-0.35 & 0.289\end{array}$

Analisis yang digunakan untuk membandingkan kelompok perlakuan dan kelompok kontrol menggunakan Independent t-test. Pada pre test diperoleh nilai $\mathrm{p}=0.031$ yang berarti terdapat perbedaan yang bermakna antara hasil pre test kelompok perlakuan dan kelompok kontrol. Hal ini mungkin terjadi karena dilihat dari rata-rata nilai yang diperoleh kelompok kontrol lebih tinggi dibandingkan kelompok perlakuan (24.30 dan 21.00). Sedangkan pada post test diperoleh nilai $\mathrm{p}=0.198$ yang berarti tidak terdapat perbedaan bermakna antara kelompok perlakuan dan kelompok kontrol. Hal ini dapat disebabkan karena pada kelompok kontrol relatif tidak banyak perubahan pada nilai post test 
(rerata 24.65) sedangkan pada kelompok perlakuan terjadi peningkatan nilai MMSE sehingga reratanya meningkat menjadi 23.10 (Tabel 3).

Tabel 3

Analisis Perbedaan Kemampuan Kognitif Pada Kelompok Perlakuan Dan Kontrol Sebelum Dan Sesudah Pemberian Latihan Fisik

\begin{tabular}{|c|c|c|c|c|}
\hline Variabel & $\mathbf{n}$ & $\begin{array}{c}\text { Mea } \\
\text { n } \\
\end{array}$ & SD & $\begin{array}{c}\mathbf{p} \\
\text { value }\end{array}$ \\
\hline \begin{tabular}{ll}
\multicolumn{2}{l}{ Sebelum } \\
perlakuan: \\
- & Kelompok \\
& perlakuan \\
- & Kelompok \\
& kontrol
\end{tabular} & $\begin{array}{l}20 \\
20\end{array}$ & $\begin{array}{c}21.0 \\
0 \\
24.3 \\
0\end{array}$ & $\begin{array}{l}4.995 \\
4.293\end{array}$ & 0.031 \\
\hline $\begin{aligned} & \text { Sesudah perlakuan: } \\
& \text { - } \text { Kelompok } \\
& \text { perlakuan } \\
& \text { - } \text { Kelompok } \\
& \text { kontrol }\end{aligned}$ & $\begin{array}{l}20 \\
20\end{array}$ & $\begin{array}{c}23.1 \\
0 \\
24.6 \\
5\end{array}$ & $\begin{array}{l}3.463 \\
4.004\end{array}$ & 0.198 \\
\hline
\end{tabular}

\section{PEMBAHASAN}

1. Karakteristik Sampel

Sampel yang memenuhi kriteria penelitian ini, baik untuk kelompok perlakuan maupun kelompok kontrol, berusia antara 50 - 70 tahun dengan rerata usia yang hampir sama, yaitu sekitar 60 tahun. Hampir seluruh sampel penelitian, baik untuk kelompok perlakuan maupun kontrol, berjenis kelamin perempuan. Dari diskusi dengan kader diperoleh informasi bahwa dalam kegiatan masyarakat, khususnya program Posyandu, partisipasi kaum laki-laki memang sangat jarang. Tingkat kehadiran lansia laki-laki dalam kegiatan rutin Posyandu pun sangat rendah. Di sisi lain, berdasarkan data demografi penduduk Desa Ngesrep jumlah penduduk perempuan, termasuk lansia, lebih banyak dibandingkan penduduk laki-laki.

Berdasarkan hasil pemeriksaan kognitif sebelum perlakuan, diketahui bahwa nilai MMSE rata-rata yang diperoleh dari sampel adalah lebih dari 20 dari total nilai maksimal 30. Secara spesifik, pada kelompok perlakuan memiliki rerata nilai MMSE 21.00 yang berarti gangguan kognitif ringan, sedangkan pada kelompok kontrol memiliki rerata 24.30 yang dapat dikategorikan tidak ada gangguan kognitif. Kelompok kontrol memiliki rerata nilai yang lebih tinggi daripada kelompok perlakuan karena sampel pada kelompok ini lebih banyak yang mengenyam pendidikan dibandingkan pada kelompok perlakuan. Telah disinggung sebelumnya bahwa beberapa komponen penilaian dalam MMSE menuntut individu untuk membaca dan menulis dan kemampuan ini umumnya dimiliki jika individu tersebut bersekolah atau menempuh pendidikan.

\section{Analisis Variabel Penelitian}

Hasil penelitian ini menunjukkan bahwa latihan fisik memberikan pengaruh yang bermakna berupa peningkatan kemampuan kognitif pada lansia kelompok perlakuan berdasarkan pemeriksaan dengan MMSE. Beberapa penelitian yang pernah dilakukan sebelumnya mendukung kesimpulan serupa.

Smith, et al. (2011) dalam Wan \& Wong (2014) mengungkapkan suatu meta analisis yang melibatkan 29 randomized controlled trial pada lansia sehat yang tidak mengalami dimensia mendapatkan bahwa aerobic exercise memperbaiki fungsi kognitif yang meliputi memori, atensi, kecepatan proses informasi, dan 
fungsi eksekutif . Penelitian meta analisis lain yang melibatkan 30 randomized controlled trial pada lansia dengan dimensia atau hendaya kognitif ringan menunjukkan bahwa latihan aerobic memperbaiki tingkat kebugaran, fungsi fisik, dan kognitif (Heyn, Abreau, \& Ottenbacher, 2004 dalam Wan \& Wong, 2014). Hal ini dimungkinkan karena latihan fisik meningkatkan ekspresi gen dan faktor-faktor yang mempengaruhi neuroplastisitas, seperti brain-derived neurotrophic factor (BDNF) dan insulinlike growth factor 1 (IGF-1) (Wan \& Wong, 2014).

Suatu artikel literature review yang melihat efek latihan fisik pada kognitif dan fungsi otak lansia mengemukakan kesimpulan yang sama, baik dari penelitian cross-sectional, studi longitudinal, maupun eksperimen, bahwa latihan fisik merupakan suatu significant moderator bagi penurunan fungsi kognitif terkait dengan proses penuaan. Hal tersebut dapat terjadi karena latihan fisik, terutama aerobic, memberikan pengaruh yang besar pada kebugaran kardiorespiratori yang diasosiasikan dengan fungsi kognitif yang lebih efisien (Bherer, Erickson, \& Liu-Ambrose, 2013). Hal ini juga diungkapkan oleh Nelson, et al (2007) dalam Kirk-Sanchez \& McGough (2014) bahwa meningkatnya resiko hendaya kognitif memiliki keterkaitan dengan beberapa faktor resiko kardiovaskuler, seperti hipertensi, dislipidemia, metabolic syndrome, diabetes yang tidak terkontrol, hyperinsulinemia yang semuanya dapat dimodifikasi dengan meningkatkan aktivitas fisik. Lebih lanjut diungkapkan bahwa menurunnya faktor resiko kardiovaskuler dan meningkatnya tingkat kebugaran diasosiasikan dengan kesehatan otak dan kemampuan kognitif yang lebih baik pada lansia, meskipun belum jelas diketahui apakah hal tersebut karena latihan fisik memediasi factor resiko kardiovaskuler yang berhubungan dengan kognitif, ataukah karena peran latihan fisik dalam neuroplastisitas (Kirk-Sanchez \& McGough, 2014).

Penelitian ini menggunakan modul latihan fisik yang tidak hanya terdiri dari latihan aerobic, tetapi menggabungkan komponen aerobic dengan latihan fleksibilitas dan pembebanan. Hasil penelitian menunjukkan bahwa gabungan model latihan ini memberikan dampak yang positif terhadap peningkatan kemampuan kognitif yang diperiksa dengan instrument MMSE. Hal ini sesuai dengan hasil penelitian Cassilhas dkk (dalam Bherer, Erickson, \& Liu-Ambrose, 2013) yang menunjukkan bahwa tipe latihan fisik yang lain, yaitu latihan dengan beban (resistance training) juga memberi manfaat pada kognitif. Cassilhas mengemukakan bahwa 6 bulan latihan beban selama 3 kali seminggu dengan intensitas sedang dan tinggi memperbaiki memori dan pembentukan konsep verbal pada 62 lansia usia 65-75 tahun yang hidup di masyarakat.

Dalam penelitian ini, dari 20 orang sampel perlakuan, 14 orang menunjukkan peningkatan nilai MMSE setelah diberikan latihan fisik selama 12 kali pertemuan. Ditinjau berdasarkan komponen kognitif dalam instrument MMSE, ditemukan bahwa 12 orang (85\%) mengalami peningkatan pada komponen memori, 9 orang $(64 \%)$ pada komponen atensi/ kalkulasi, 8 orang $(57 \%)$ pada komponen orientasi, dan 5 orang $(35 \%)$ pada komponen bahasa (pemahaman instruksi). Berdasarkan data tersebut terlihat bahwa latihan fisik memberikan 
pengaruh pada perbaikan kemampuan kognitif, terutama pada fungsi mengingat (memori). Hasil ini sesuai dengan penelitian Cassilhas dkk yang mendapati subyek penelitiannya juga mengalami perbaikan memori setelah dilakukan latihan dengan pembebanan selama 6 bulan.

Mekanisme peningkatan fungsi kognitif sebagai efek dari latihan fisik dapat dilihat sebagai efek biologis secara langsung maupun tidak langsung. Spirduso et al (2005) dalam Bherer, Erickson, \& Liu-Ambrose (2013) mengemukakan efek biologis tidak langsung timbul karena latihan fisik memperbaiki kondisi kesehatan secara umum (menurunkan stress, meningkatkan kualitas tidur) serta mengurangi resiko penyakit kronis (mis. Penyakit jantung koroner) yang berdampak pada fungsi neurokognitif. Sedangkan efek langsung latihan terhadap kognitif pada awalnya diketahui berdasarkan eksperimen dengan binatang. Lista dan Sorrentino (2010) dalam Bherer, Erickson, \& Liu-Ambrose (2013) mengemukakan mekanisme biologis yang berhubungan dengan latihan fisik terjadi pada 2 level, yaitu supramolekular dan molecular. Pada level supramolekular latihan fisik memfasilitasi angiogenesis, yaitu munculnya pembuluh darah baru dari pembuluh darah yang telah ada, neurogenesis atau proliferasi sel neural pada hipokampus, dan synaptogenesis, di mana neuron baru yang terbentuk mampu berintegrasi dengan jaringan neural dan bekerja fungsional. Selain itu, system neurotransmitter juga dimodulasi melalui latihan fisik. Studi terakhir menunjukkan bahwa latihan fisik berpengaruh terhadap peningkatan volume hippocampus melalui peningkatan BDNF. Adanya peningkatan volume hippocampus ini memberikan pengaruh pada peningkatan fungsi memori (Erickson et al, 2011 dalam Bherer, Erickson, \& LiuAmbrose, 2013). Mekanisme inilah yang mungkin terjadi pada kelompok perlakuan dalam penelitian ini.

Penelitian pada manusia menggunakan brain imaging menemukan bahwa latihan fisik mempengaruhi perubahan struktur dan fungsi otak secara permanen. Colcombe et al. (2003) mengungkapkan bahwa peningkatan kebugaran kardiorespiratori yang dinyatakan dengan VO2 max berasosiasi dengan penurunan hilangnya grey dan white matter pada regio frontal, prefrontal, dan temporal akibat penuaan. Sedangkan Erickson et al. (2009), dengan menggunakan MRI menemukan bahwa semakin tinggi tingkat kebugaran lansia berasosiasi dengan volume hippocampus kanan dan kiri yang lebih besar yang berdampak pada performa memori spasial yang lebih baik (Bherer, Erickson, \& LiuAmbrose, 2013).

Berdasarkan paparan di atas, dapat disimpulkan bahwa latihan fisik memberikan pengaruh positif terhadap fungsi kognitif karena memperbaiki factor resiko cardiovaskuler serta mempengaruhi factor-faktor neurotropis yang keduanya bertanggung jawab terhadap kesehatan otak dan mempengaruhi performa kognitif.
3. Keterbatasan Penelitian
Berdasarkan pelaksanaan penelitian yang telah dilakukan, ditemukan beberapa hal yang menghambat atau mempengaruhi hasil penelitian sehingga perlu dipertimbangkan dalam pelaksaan penelitian selanjutnya, antara lain: 
a. Penggunaan instrumen MMSE untuk menilai kemampuan kognitif pada sampel penelitian ini tampaknya kurang tepat, karena pemeriksaan ini menuntut kemampuan baca tulis serta pengetahuan umum (mis. nama propinsi, kabupaten/kota) yang umumnya diperoleh melalui pendidikan. Sedangkan banyak lansia yang berada di wilayah penelitian ini yang tidak pernah mengenyam pendidikan atau bersekolah. Selain itu, banyak di antara lansia tersebut yang tidak memahami bahasa Indonesia dengan baik sedangkan instrumen ini menggunakan bahasa Indonesia sebagai pengantarnya. Masalah yang lain adalah pemahaman mengenai waktu yang berbeda. Banyak lansia yang diwawancarai menggunakan kalender Jawa sebagai penentu waktu sehingga mereka kebingungan saat harus menyebutkan waktu (tanggal, bulan, tahun) dalam kalender nasional.

b. Sulit mendapatkan sampel sesuai kriteria inklusi yang direncanakan terkait dengan usia, karena lansia yang berusia 60 tahun ke atas jumlahnya tidak terlalu besar. Selain itu, lansia pada usia ini banyak yang sudah tidak aktif dan menolak untuk berpartisipasi sebagai responden. Oleh karena itu, batas usia untuk sampel diturunkan menjadi 50 tahun.

c. Lokasi tempat tinggal menjadi pertimbangan dalam pemilihan kelompok kontrol dan perlakuan karena wilayah Desa Ngesrep ini cukup luas. Jika tempat tinggal subyek penelitian cukup dekat satu dengan yang lain diharapkan mereka dapat datang dan berkumpul untuk melaksanakan kegiatan senam. Namun peneliti kurang jeli mencermati bahwa kelompok kontrol yang tinggal lebih mendekati pusat pemerintahan desa dan perkotaan dibandingkan dengan kelompok perlakuan, lebih terpapar informasi dan memiliki tingkat pendidikan yang lebih baik sehingga berpengaruh pada nilai MMSE.

d. Tempat yang kurang luas serta cuaca yang sering hujan menjadi kendala dalam pelaksanaan latihan fisik (senam).

\section{KESIMPULAN DAN SARAN}

1. Subjek penelitian ini sejumlah 40 lansia, terdiri dari 20 orang kelompok perlakuan dan 20 orang kelompok kontrol dengan usia 50 - 73 tahun dan $95 \%$ perempuan.

2. Berdasarkan pemeriksaan dengan MMSE, rata-rata nilai sebelum diberikan perlakuan pada kelompok perlakuan $21.00(\mathrm{SD}=$ 4.995) dan kelompok kontrol $24.30(\mathrm{SD}=4.293)$. Setelah diberikan perlakuan rerata nilai kelompok perlakuan menjadi $23.10(\mathrm{SD}=3.463)$ sedangkan kelompok kontrol 24.65 (SD = 4.004).

3. Berdasarkan analisis Paired t-test kelompok perlakuan pada tingkat signifikansi $\alpha=0.05$ diperoleh $\mathrm{t}$ statistik $2.492>\mathrm{t}$ tabel 2.093, nilai $\mathrm{p}=0.022$ dengan $\mathrm{r}=0.657$, sehingga secara statistik disimpulkan bahwa terdapat perbedaan yang bermakna pada 
kemampuan kognitif lansia antara sebelum dan setelah pemberian latihan fisik, di mana latihan fisik memberikan pengaruh yang kuat dan positif pada kemampuan kognitif. Pada kelompok kontrol diperoleh nilai $\mathrm{p}=0.053$ sehingga disimpulkan tidak terdapat perbedaan kemampuan kognitif sebelum dan sesudah perlakuan.

4. Berdasarkan analisis Independent t-test antara kelompok perlakuan dan kontrol, diperoleh nilai $\mathrm{p}=$ 0.031 sebelum perlakuan, yang berarti terdapat perbedaan yang bermakna pada kemampuan kognitif kelompok kontrol dan kelompok perlakuan, di mana kelompok kontrol memiliki kemampuan kognitif yang lebih tinggi dibandingkan kelompok perlakuan. Setelah intervensi latihan fisik diperoleh $\mathrm{p}=0.198$, yang berarti tidak terdapat perbedaan yang bermakna pada kemampuan kognitif kelompok perlakuan dan kontrol karena terdapat peningkatan nilai kognitif pada kelompok perlakuan sedangkan pada kelompok kontrol relatif tidak banyak perubahan.

5. Terdapat pengaruh latihan fisik terhadap kemampuan kognitif lansia pada kelompok perlakuan.

Beberapa hal yang dapat disarankan bagi penelitian selanjutnya adalah:

1. Pemilihan instrument yang digunakan dalam penelitian perlu mempertimbangkan juga karakteristik dari subyek yang akan diteliti, karena hal ini akan berpengaruh terhadap pelaksanaan pemeriksaan dan hasil yang diperoleh.

2. Perlu dilakukan survey awal terhadap subyek yang akan diteliti sehingga penetapan kriteria serta kelompok sampel dapat direncanakan secara tepat.

3. Perlu mempertimbangkan faktorfaktor lain yang berpengaruh pada pelaksanaan penelitian, seperti cuaca dan lokasi, terutama jika penelitian dilaksanakan di luar ruangan.

\section{DAFTAR RUJUKAN}

Badan Perencanaan Pembangunan Nasional., (2007). Jumlah Lansia 2025 Diproyeksikan 62,4 Juta Jiwa. Jakarta, 12 November 2007. Diakses 15 September 2011 dari http://persreleaseforumjakartauntu kperlindunganlansiadigelardibappe nas_2008112314259_1064_0.pdf

Bherer, L., Erickson, K.I. \& Liu-Ambrose, T. (2013). A Review of the Effects of Physical Activity and Exercise on Cognitive and Brain Functions in Older Adults. Journal of Aging Research, vol 2013, article ID 657508.

http://dx.doi.org/10.1155/2013/657 508. Diakses Oktober 25, 2016. Dari www.ncbi.nlm.nih.gov

Dewi, S.Y., Danardi., Dharmono S., Heriawan, C., Aries, W., dan Ariawan, I. (2007). Faktor-faktor yang berperan terhadap terjadinya Depresi pada Pasien Geriatri yang di rawat du RS Dr. Cipto Mangunkusumo. Dalam Cermin Dunia Kedokteran Vol.34 no.3/156 Depresi Tahun 2007. Jakarta: Grup PT Kalbe Farma Tbk. 
Mental Health Foundation. (2012). Exercise and Mental Health. Diakses 13 Maret, 2012, dari http://www.mentalhealth.org.uk/he lp-information/mental-health-az/E/exercise-mental-health/

Myers, J.S. (2008). Factors Associated with Changing Cognitive Function in Older Adults: Implications for Nursing Rehabilitation. Rehabilitation Nursing; May/Jun 2008; 33, 3; ProQuest Medical Library pg. 117. Diakses 22 Maret 2010 dari: http://proquest.umi.com/pqdweb?

National Institute on Aging. (2015). Assessing Cognitive Impairment in Older Patients. A Quick Guide for Primary Care Physicians. Diakses Februari, 21, 2016. Dari www.nia.nih.gov/alzheimers/publi cation/assessing-cognitiveimpairment-older-adults.

Powers, S.K. \& Howley, E.T. (2001). Exercise Physiology - Theory and Application to Fitness and Performance $\left(4^{\text {th }} e d\right)$. New York: McGraw Hill

Wan, M. \& Wong, R.Y (2014). Benefits of Exercise in The Elderly. CGS Journal of CME, vol 4, issue 1, 2014. Diakses Oktober, 25, 2016. Dari eurapa.biomedcentral.com

Wilmore, J.H., Costill, D.L. \& Kenney, W.L. (2008). Physiology of Sport and Exercise $\left(4^{\text {th }} e d\right)$. Illinois: Human Kinetics 